\title{
Employment characteristics and partnership formation among lone mothers in Russia
}

\author{
Partnerschaftsbildung alleinerziehender Mütter in Russland: \\ Welchen Einfluss haben Berufsmerkmale?
}

\begin{abstract}
:
Lone mothers' poverty rates in Russia were very high in the period following the transition in 1991, and earnings inequalities between women increased. The aim of this paper is to examine to what extent lone mothers' economic situation may have also influenced their rates of partnership formation. This can add to an understanding of how the influence of growing economic inequalities extends to other areas of the life course as well. The data used is from the Russian Generations and Gender Survey (GGS), and methods of event-history analysis are applied for the empirical investigations. The effect of occupation on partnership formation is compared before and after the transition, as earnings differences between those working in different occupations grew after 1991. The results indicate that lone mothers working in service occupations, in particular, had substantially higher rates of partnership formation than those working in higher-paying professional occupations requiring a university degree, both before and after the transition in 1991. However, no large changes in the effect of occupation on partnership formation are found for the period after 1991 compared to the period before transition.
\end{abstract}

Key words: lone mothers, Russia, partnership formation, occupation, event-history analysis

\section{Zusammenfassung:}

Armutsraten von alleinerziehenden Müttern in Russland waren in der Zeit nach dem politischen und ökonomischen Umbruch im Jahr 1991 besonders hoch, und Einkommensungleichheiten zwischen Frauen nahmen in dieser Periode ebenfalls zu. Daher ist die Fragestellung in dieser Studie, inwiefern die ökonomische Situation von Alleinerziehenden auch ihre Übergangsraten in neue Partnerschaften beeinflusst hat. Dies kann dazu beitragen, zu verstehen, inwiefern wachsende ökonomische Ungleichheiten sich auch auf andere Bereiche des Lebenslaufs auswirken. Die empirischen Analysen beruhen auf Daten des russischen Generations and Gender Survey (GGS). Es wird der Einfluss des Berufs auf Partnerschaftsbildungsraten von Alleinerziehenden vor und nach 1991 anhand von Übergangratenmodellen untersucht. Die Ergebnisse zeigen, dass Alleinerziehende, die im Dienstleistungsbereich arbeiteten, sowohl vor wie auch nach 1991 deutlich höhere Partnerschaftsbildungsraten hatten als Alleinerziehende, die in höher entlohnten Berufen arbeiteten, die einen Universitätsabschluss voraussetzten. Allerdings wurden keine bedeutenden Veränderungen im Einfluss des Berufs auf Partnerschaftsbildungsraten nach 1991, im Vergleich zu vor 1991 gefunden.

Schlagwörter: Alleinerziehende, Russland, Partnerschaftsbildung, Beruf, Ereignisanalyse 


\section{Introduction}

Poverty rates were very high for lone mother families in the period after the transition in Russia in 1991. Inequality generally rose, and income differences between women working in different occupations increased as well. Those working in low-paying occupations are particularly likely to have suffered from economic hardships. This study aims to examine to what extent growing income inequality after 1991 in Russia also led to a greater influence of socio-economic status on partnership formation. An influence of socioeconomic status on partnership could indicate that lone mothers with economic difficulties entered partnerships towards which they would have been more hesitant to consider under other circumstances. This could be evaluated as a further negative consequence of economic difficulties for lone mothers after the transition in Russia. On the other hand, if partnership formation provided a possible route out of poverty, this could also be viewed positively. Overall, the purpose of this study is not to evaluate whether an effect of socioeconomic status on partnership formation should be perceived as being positive or negative in a normative sense. Rather, the aim is to contribute to an understanding of how economic difficulties may influence long-term decisions in other important areas of the life course, such as partnership formation.

While inequality increased in Russia after the transition in 1991, relevant earnings differentials did already exist between women working in different occupations before the transition as well. Thus, effects of occupation on partnership formation are also expected for the period before 1991. However, the occupation effect is expected to increase after 1991 along with increased income inequalities.

The data used for the empirical analyses are from the Russian Generations and Gender Survey (GGS) and from the corresponding Education and Employment Survey (EES), both conducted in 2004/05. The analyses of lone mothers' partnership formation rates are carried out using event-history analysis, and are based on the longitudinal, retrospective sections of the GGS and EES.

The structure of the paper is as follows. The next section discusses theoretical considerations and previous international research on effects of employment characteristics on lone mothers' partnership formation. The subsequent two sections provide overviews on lone mothers' economic situation as well as on earnings differentials among women in Russia. After a summary of the main hypotheses, the data and method of analysis are discussed in section six. Section seven presents the empirical findings for the influence of employment characteristics on lone mothers' rates of partnership formation both before and after the transition in Russia. The conclusion then draws together the main findings.

\section{Theoretical considerations and international research on the influence of socio-economic factors on partnership formation}

This section discusses general theoretical considerations on the connection between socioeconomic factors and partnership formation, and also reviews international empirical studies on partnership formation among lone parents. The subsequent sections will then 
give an overview of lone mothers' economic situation in Russia, and discuss the implications of the international literature reviewed in this section for the Russian context.

Many different considerations have been put forward on how women's socioeconomic resources, as indicated by employment, occupation, earnings, and level of education, could influence repartnering. On the one hand, women with higher levels of socioeconomic resources and better earnings abilities usually are under less economic pressure to begin a new partnership (Bumpass et al 1990; Smock 1990; de Graaf/Kalmijn 2003). They would also profit less from traditional gender-specific divisions of labor in the household (Jenkins et al 1990; Sweeney 1997). A number of studies have also shown that it is disproportionately uncommon for women to have a higher level of education than their partner, and that women are reluctant to engage in relationships with men who have a lower level of education than their own (Blossfeld/Timm 1997; Blossfeld/Timm 2003; Skopek et al 2011). This implies that women with higher levels of education have a smaller number of potential partners to choose from, which should be expected to result in lower partnership formation rates.

On the other hand though, women with better earnings prospects may be more attractive to potential partners, since they can contribute more to the household income (Bumpass et al 1990; Sweeney 1997; de Graaf/Kalmijn 2003). Women with higher levels of socio-economic resources may also be more likely to meet a partner with similar characteristics and profit more from marriage (Chiswick/Lehrer 1990; Jenkins et al 1990; Smock 1990). Being employed could also influence partnership formation by offering additional opportunities to meet new people (Ermisch/Wright 1991; de Graaf/Kalmijn 2003). Or, expressed in Blau's (1994) terms, by being employed, people become members of a further social group, and can therefore profit from opportunities for additional in-group relations.

Findings for the effect of education have been somewhat mixed. Le Bourdais et al. (1995) as well as Wu and Schimmele (2005) find a positive effect of level of education on lone mothers' entries into partnerships or women's repartnering in general, while Lefebvre and Merrigan (1998) find negative effects on lone mothers' repartnering. By constrast, Meggiolaro and Ongaro (2008), de Graaf and Kalmijn (2003), and Sweeney (1997), find no effects of level of education on women's repartnering or remarriage in general.

Findings for the effect of current employment are more consistent. Most studies find either a negative or no effect of employment on partnership formation (e.g. Le Bourdais et al 1995; Böheim/Ermisch 1998; de Graaf/Kalmijn 2003; Wu/ Schimmele 2005; Meggiolaro/Ongaro 2008). A study conducted by Ermisch and Wright (1991) however finds a positive employment effect for the subgroup of never-married lone mothers.

Very few studies have examined the effect of income or occupation on lone mothers' partnership formation or on repartnering in general. However, Lampard and Peggs (1999) find for Great Britain that women in professional occupations generally have lower repartnering rates than those working in occupations requiring lower qualifications. Similarly, Dooley and Finnie (2008) find a negative effect of earned income on lone mothers' partnership formation in Canada. Thus, these studies find that those earning higher incomes have lower partnership formation rates. Studies looking at different subgroups sometimes find contrasting results. While Ermisch and Wright (1991) also find that work- 
ing in non-manual occupations is associated with lower partnership formation rates for previously married lone mothers, they find no effect at all for never-married lone mothers in Great Britain. Sweeney (1997) also finds that a higher occupational status is associated with lower remarriage rates for younger women, but finds the reversed effect for older women in the United States.

Thus, altogether, while findings for level of education have been somewhat mixed, there seems to be a tendency towards negative effects of current employment and occupational status on lone mothers' partnership formation or repartnering in general.

The next two sections give an overview over lone mothers' economic situation and earnings inequalities in Russia. Subsequently, section 5 formulates hypotheses for the empirical analyses, by drawing together considerations based on the international literature that was reviewed in this section and lone mothers' specific situation in Russia which will be discussed in sections 3 and 4 .

\section{Income inequality among women in Russia}

As discussed above, international empirical studies tend to find higher partnership formation rates for lone mothers earning lower wages. This section reviews research showing that important earnings inequalities between women working in different occupations existed in Russia before the transition as well. After the transition, however, inequality increased substantially. Thus, the research question in the present study is whether there is a relationship between occupation and partnership formation in Russia both before and after the transition. Furthermore, this study examines whether occupation effects on lone mothers' partnership formation grew stronger after the transition in 1991 along with rising income inequality.

Even for the time before the transition, evidence has been found of occupational and educational wage differences between women. Gustafsson et al. (2001) calculate a Gini coefficient of 0.206 for wages of female workers aged 25-55 in 1989 in Taganrog, which is considered to be a typical Russian industrial city. Education was found to significantly affect wages, even more so for women than for men. Women working as managers had the highest wages, followed by manual workers, then professionals, and finally office workers. Workers in transportation, trade and service, as well as public service had lower wages than workers in manufacturing or construction.

While important wage differences existed among women even before the transition, there is also evidence of changes in earnings by occupation after 1991. Newell and Reilly (1999) find that returns to education increased across the early 1990s, but explain only a fraction of the general rise in inequality. These findings apply to men as well as women. Gerber and Hout (1998) also find increases in the effect of education on wages for women across the early 1990s, while they did not detect such an effect for men. In addition, the authors find that wages of professionals increased relative to both skilled manual workers in general and unskilled manual and non-manual workers in the state sector - but not to those working in the private sector. The wage advantage of managers relative to professionals also increased. Skilled manual workers were not able to improve their position relative to unskilled workers. Lower routine non-manual workers had the lowest wages 
during the whole period of investigation. Further findings are that the cognitive sector lost relative to industry, but that the service sector has gained relative to the industrial sector.

Table 1 gives an overview of women's mean monthly earnings by occupation for the year 2004 based on GGS data. The second column shows which proportion of female employees were employed in a given occupational group. Here it can be seen that the group of female managers is extremely small, though in 2004 they continued to earn considerably higher wages than others. Professionals are the second highest earning group, closely followed by technicians, associate professionals, and plant and machine operators and assemblers. Clerks (office workers) may have earned little before the transition, but that no longer seems to be as much the case. The lowest earning groups are agricultural workers and workers in elementary occupations, though the former group again is very small. Service and sales workers have the third lowest earnings.

Table 1: Women's mean monthly earnings by occupation (2004)

\begin{tabular}{lcc}
\hline & & $\begin{array}{c}\text { distribution of female } \\
\text { employees across } \\
\text { occupations }\end{array}$ \\
\hline legislators, senior officials, managers & $\begin{array}{c}\text { mean earnings (rubles) } \\
\text { professionals }\end{array}$ & $3 \%$ \\
technicians and associate professionals & 5960 & $21 \%$ \\
clerks & 3758 & $12 \%$ \\
service workers and shop and market sales workers & 3623 & $8 \%$ \\
skilled agricultural and fishery workers & 3304 & $13 \%$ \\
craft and related trade workers & 2856 & $2 \%$ \\
plant and machine operators and assemblers & 1973 & $19 \%$ \\
elementary occupations & 3457 & $13 \%$ \\
\hline
\end{tabular}

$\mathrm{N}=3460$

Source: GGS 2004 (own calculations), weighted to adjust for sampling design

\section{Lone mothers' economic situation in Russia}

The previous section summarized research on earnings inequalities between women before and after the transition. After the transition in 1991, there is evidence of rising earnings inequality and increasing returns to education among women. This section summarizes studies on rising poverty rates among lone mothers across the 1990s. It seems plausible to expect that partnership formation rates are elevated particularly for those in economically very difficult situations. Perhaps lone mothers in very difficult economic situations tend more often to enter partnerships towards which they would have been more reluctant under other circumstances. If this is the case, then investigating connections between lone mothers' socio-economic status and partnership formation should be particularly relevant in contexts where economic deprivation is frequent.

For Russia, households containing lone mother families have been found to have the highest poverty rates of all household types, despite high employment rates. Using absolute poverty measures, Lokshin et al. (2000) find that the poverty rate for all household types was around 11\% in 1992 and reached 35\% in 1996, but climbed from around 23\% 
in 1992 to nearly 40\% in 1996 for households with lone parents. Kanji (2004) finds for the year 2000 that $26.6 \%$ of all children lived in poor households, while children living with lone mothers had a poverty rate of $35.2 \%$. According to McKinney (2004), there is also some evidence of higher poverty rates for lone mother families in the pre-transition period.

The gender wage gap is likely to be one reason for lone mothers' high poverty rates. Several studies have found evidence that a gender wage gap comparable to Western countries already existed in the Soviet Union (Newell/Reilly 1996; Brainerd 2000; Pascall/Manning 2000; Hansberry 2004). According to a number of studies, the gender gap in monthly wages initially seems to have grown somewhat larger at the beginning of the 1990s (van der Lippe/Fodor 1998; Ogloblin 1999; Brainerd 2000; Trapido 2007), while other studies found little change in the monthly and hourly wage ratio respectively (Newell/Reilly 1996; Pascall/Manning 2000).

While the gender pay gap found for Russia both before and after 1991 is not much different from that in most Western countries, its impact on lone mothers' poverty rates may have been particularly strong. Wages at the beginning of the 1990s generally were not very high, as pointed out by Pascall and Manning (2000). Given a wage level that is generally low, even a moderate gender wage gap can contribute to large differences in poverty rates between lone mother households and other household types, as measured by absolute poverty measures. A low wage level is also likely to have generally made it very difficult for families to live on only one income.

Table 2 shows estimates of mothers' employment rates by partnership status and age of the youngest child, based on GGS data for 2004. Here we can see that lone mothers are more likely to be employed than mothers with a partner. Other studies, referring to the mid-1990s and the beginning of the $21^{\text {st }}$ century, likewise find higher employment rates for lone mothers in Russia than for married mothers (Kanji 2004; Lokshin 2004; Teplova 2007).

While lone mothers' employment rates in Russia are comparatively high, over $30 \%$ are nevertheless not employed full-time. Lone mothers do not seem to have had much access to other sources of income. Support from alimony payments has for instance been low. This often has to do with difficulties enforcing alimony payments or with the low level of men's own earnings (Pascall/Manning 2000; Kanji 2004). Contributions from state benefits have also been quite low. Although families in Russia have access to a number of different types of allowances and lone mothers are additionally entitled to special benefits, real values of benefits have often been nearly negligible (Generations and Gender Contextual Data Base 2011; Pascall/Manning 2000; Kanji 2004; McKinney 2004; Rieck 2006; Teplova 2007).

The next section presents hypotheses for the empirical analyses, drawing together considerations based on the international literature on determinants of lone mothers' partnership formation discussed in section 2, with the specific situation in Russia, discussed above. 
Table 2: Mothers' employment status by partnership status and age of the youngest child

\begin{tabular}{|c|c|c|c|c|c|c|c|}
\hline $\begin{array}{l}\text { age of the } \\
\text { youngest child }\end{array}$ & full-time & part-time & $\begin{array}{c}\text { employm } \\
\text { maternity/ } \\
\text { parental } \\
\text { leave }\end{array}$ & $\begin{array}{l}\text { nt status } \\
\text { non- } \\
\text { employed }\end{array}$ & student & $\begin{array}{l}\text { otherl } \\
\text { missing }\end{array}$ & total \\
\hline \multicolumn{8}{|l|}{ lone mothers } \\
\hline 0 years & $2 \%$ & $0 \%$ & $64 \%$ & $34 \%$ & $0 \%$ & $0 \%$ & $100 \%$ \\
\hline $1-2$ years & $34 \%$ & $2 \%$ & $33 \%$ & $30 \%$ & $1 \%$ & $0 \%$ & $100 \%$ \\
\hline $3-6$ years & $67 \%$ & $3 \%$ & $0 \%$ & $26 \%$ & $1 \%$ & $1 \%$ & $100 \%$ \\
\hline 7 - 15 years & $78 \%$ & $2 \%$ & $1 \%$ & $16 \%$ & $1 \%$ & $2 \%$ & $100 \%$ \\
\hline all & $67 \%$ & $2 \%$ & $8 \%$ & $21 \%$ & $1 \%$ & $2 \%$ & $\begin{array}{c}100 \% \\
N=542\end{array}$ \\
\hline \multicolumn{8}{|l|}{ 2-parent household } \\
\hline 0 years & $4 \%$ & $1 \%$ & $65 \%$ & $23 \%$ & $6 \%$ & $0 \%$ & $100 \%$ \\
\hline $1-2$ years & $21 \%$ & $4 \%$ & $44 \%$ & $28 \%$ & $2 \%$ & $1 \%$ & $100 \%$ \\
\hline $3-6$ years & $69 \%$ & $3 \%$ & $3 \%$ & $23 \%$ & $1 \%$ & $1 \%$ & $100 \%$ \\
\hline 7 - 15 years & $70 \%$ & $4 \%$ & $1 \%$ & $23 \%$ & $0 \%$ & $2 \%$ & $100 \%$ \\
\hline all & $57 \%$ & $4 \%$ & $13 \%$ & $24 \%$ & $1 \%$ & $1 \%$ & $\begin{array}{c}100 \% \\
N=1.537\end{array}$ \\
\hline
\end{tabular}

data is weighted to adjust for sampling design

source: GGS 2004 (own calculations)

\section{Hypotheses on effects of employment characteristics on lone mothers' partnership formation in Russia}

As discussed earlier, not many studies have investigated effects of occupation on lone parents' partnership formation or repartnering in general. Those studies have tended to find higher partnership formation rates for those working in lower-paying occupations. It seems that greater economic need among lone mothers with lower incomes leads them to decide to begin a new partnership more quickly. I would likewise expect to find higher partnership formation rates among lone mothers working in lower-paying occupations in Russia $^{1}$. A hypothesis would be that such differences in partnership formation rates already existed prior to the transition. Even before 1991, as discussed above, there were important earnings inequalities between women working in different occupations, and the economic situation for lone parents with low earnings is likely to already have been quite difficult. After 1991, however, inequality generally increased, and as discussed above, earnings inequalities increased among women as well. Returns to education generally increased for women, and women working as managers or professionals gained in terms of earnings relative to those working in occupations requiring lower qualifications. Thus a

1 The only previous finding of higher partnership formation rates for those working in higher status occupations applied to older women in the United States (Sweeney 1997). Since the mean age at first birth is quite low in Russia, at approximately 23 both in the 1980s and 1990s (Philipov/ Jasilioniene 2008), I would not expect this effect to generally apply to lone mothers in the Russian context. 
further hypothesis is that occupational differences in partnership formation rates became stronger for lone mothers after 1991.

Like most surveys, the Generations and Gender Survey (GGS) analyzed here does not contain retrospective income information. Women's earnings in Russia have however been found to be correlated with qualification and occupation, both before and after 1991, as described above. Retrospective, longitudinal information on qualification and occupation is available in the GGS data. This study will examine the impact of lone mothers' employment status and occupation on partnership formation.

With respect to employment status, an effect is not expected until after 1991. At least officially, unemployment did not exist before the transition. However, after 1991, unemployment did begin to occur, although not on a very high level (Lokshin 2004; Federal State Statistics Service 2005). While childcare provision still appears to be quite high in international comparison, it is far from universal (Pascall/Manning 2000; McKinney 2004; Oberemko 2006). This may have made employment difficult for some lone mothers, especially for those with very young children.

\section{Data and method}

The data used for the empirical analyses is from the Russian Generations and Gender Survey (GGS), and from the corresponding Education and Employment Survey (EES). The international Generations and Gender Surveys are coordinated by the Population Activities Unit (PAU) of the United Nations Economic Commission for Europe (UNECE). The Gender and Generations Surveys focus on the fields of fertility and family dynamics, home-leaving, and retirement (United Nations Economic Commission for Europe 2007). The Russian GGS data were collected by the Independent Institute of Social Policy (Moscow) in 2004. They contain complete fertility and partnership histories. The EES, conducted in 2005, is a follow-up for a sub-sample of the GGS. The EES contains complete education, employment, and migration histories. For the following analyses, retrospective, longitudinal data from the GGS and the EES were combined and analyzed together. ${ }^{2}$

The period of investigation refers to the years 1966 to 2004, since retrospective information from both the GGS and the EES is available for this period. Only respondents who participated in both the GGS and EES were included in the analyses. The method of analysis chosen to study factors influencing partnership formation among lone mothers is event-history analysis. This makes it possible to account for a number of time-varying variables available from the retrospective histories collected in the GGS and EES.

The models estimated for the empirical analyses can generally be represented by the following formula:

2 The Russian GGS was conducted by the Independent Institute of Social Policy (Moscow) with the financial support of the Pension Fund of the Russian Federation and the Max Planck Society, Germany. The design and standard survey instruments of the GGS were adjusted to the Russian context by the Independent Institute of Social Policy (Moscow) and the Demoscope Independent Research Center (Moscow) in collaboration with the Max Planck Institute for Demographic Research (Rostock, Germany). 


$$
\ln \mathrm{h}_{\mathrm{i}}(\mathrm{t})=\mathrm{y}(\mathrm{t})+\sum_{j=1}^{m} \beta_{j} x_{i j}+\sum_{k=m+1}^{n} \beta_{k} x_{i k}(t)
$$

The dependent variable is the log risk (intensity) of partnership formation $\ln h_{i}(t)$. The baseline duration used is age $(t)$. Time-varying independent variables are given by $\mathrm{x}_{i k}(t)$ and time-constant independent variables are given by $x_{i j}$. The time-varying variables include the number of children, the age of the youngest child, whether the respondent is currently pregnant, the duration since the last partnership, employment status, occupation, and the size of the settlement in which the respondent is living. Education is not included in the model because it is too strongly correlated with occupation. The occupation variable differentiates between unqualified workers, qualified manual workers, workers in the service sector, office or clerical employees, professionals with post-secondary education in medicine, teaching, or natural sciences, professionals with post-secondary education in a different subject, and professionals with university education or senior or top managers. The variable for settlement size differentiates between a) centers of a region, territory, or republic, b) other towns or cities, c) urban-type villages, and d) villages. The only timeconstant variable is religious denomination, differentiating between Russian Orthodox, Islam, or a different denomination (including no denomination).

Both entries into cohabiting unions and marriages are considered to be partnership formations. Entries into cohabitations have strongly increased in recent years, and direct marriages have become rarer (Hoem et al 2009). Lone mothers' living situation is likely to change strongly upon entry into either cohabitation or direct marriage, and it is this change that is the focus of the present study. Changes in mothers' living situation are likely to be much smaller if they subsequently marry their partners after cohabitation. Determining differences in factors influencing entries into direct marriages as opposed to cohabitations would be a separate research question. Here, the aim is rather to study exits from lone motherhood.

Respondents come under risk of partnership formation as soon as they become lone mothers. Episodes are censored when the youngest child reaches age 15, or when all children have moved out of the household. During the period of investigation, there were 673 partnership formations. Altogether, there were 1775 spells of lone motherhood and 1527 corresponding respondents, as some respondents were lone mothers more than once. Clustering was accounted for in the analyses, but this did not alter the results. Kish weights were used to account for the household sampling design. In order to provide a basis of comparison, an additional model was estimated for childless single women's risks of partnership formation.

Unfortunately, the survey response rate in Moscow and St. Petersburg was especially low. Therefore, a variable controlling for whether the respondent was living in Moscow or St. Petersburg was included in the model in addition to the standard variable for settlement size. However, living in Moscow or St. Petersburg had no significant effect on risks of partnership formation.

Tables 1 and 2 above presented figures based on cross-sectional information from the GGS. The variables used there only refer to the year 2004. Information on income, for example, was available only cross-sectionally and not retrospectively. The empirical analyses discussed in the next section, by contrast, are based on the retrospective, longitudinal 
sections of the GGS and EES. These analyses use the variables available from the retrospective histories described in this section and refer to the years 1966-2004.

\section{Results}

As discussed above, a first hypothesis in this study is that lone mothers working in occupations associated with higher earnings have lower partnership entry rates. This is expected to apply before as well as after 1991, as important inequalities in female earnings already existed in Russia even before the transition. A further hypothesis is that the effect of occupation is stronger in the period after 1991, since some occupations gained relative to others in terms of earnings after the transition.

Findings in Table 3 do indicate differences in lone mothers' rates of partnership formation by occupation. High rates of partnership formation are found for lone mothers working in occupations associated with low earnings. These are service occupations both before and after 1991, and office work, where women had particularly low earnings before 1991. Lone mothers who were professionals or managers, on the other hand, were found to have comparatively low risks of partnership formation in both time periods. Women in this group were among those with the highest earnings in both time periods. Skilled manual workers also had comparatively high wages, though, as discussed above, they appear to have lost relative to professionals after 1991. Indeed, partnership formation rates for lone mothers who are skilled manual workers are higher relative to professionals with a university degree after than before 1991. The only group for whom findings are not as expected are the unskilled workers. Unskilled workers are one of the groups with the lowest earnings. Yet, their risks of partnership formation are also low.

Thus, altogether, these findings add to the international evidence of higher partnership formation rates for lone mothers in lower-paying occupations. As of yet, only a small number of studies, focusing on Western European and North American countries, have looked into the effect of occupation on lone mothers' partnership formation. The present study indicates that lone mothers in Russia, too, tend to have higher partnership formation rates when their earnings are low, and it gives evidence that such an effect existed prior to the transition as well.

These findings can be taken to indicate that lone mothers' occupation influences their partnership formation rates via their earnings. However, other interpretations are also possible. For example, lone mothers working in service occupations might meet more new people on a regular basis than do employees in other occupations. That is, they may have greater opportunities to associate with people outside their closest social group (Blau 1994).

Altogether, the findings confirm the first hypothesis that those in lower-paying occupations would have higher partnership formation rates in both time periods. However, contrary to the expectations expressed in the second hypothesis, differences in partnership formation rates between those working as managers or professionals and those working in service occupations or as qualified manual workers only increased very slightly after the transition in 1991, along with growing income differences. Partnership formation rates can also be compared directly across time periods for a given occupation. For instance, 
partnership entry rates for those working in service occupations only increased by $8 \%$ $(1.87 / 1.73=1.08)$ after 1991 , and for qualified manual workers only by $17 \%(1.47 / 1.26$ $=1.17)$. This may indicate that there is an upper limit to the influence of lone mothers' economic situation on rates of partnership formation. It is likely that lone mothers can make adjustments to some extent as to whether and how quickly they decide to begin a new partnership. However, it seems that they are not able to increase their partnership formation rates indefinitely.

Another explanation for the limited changes in the effect of occupation after the transition may be that those who experienced large income gains were quite a small group. As discussed above, managers had substantially higher earnings than women employed in other occupations after the transition. Yet, they only represented 3\% of the sample. In the analyses, it was thus not possible to estimate effects for managers as a separate occupational group, and they were grouped together with professionals. If it had been possible to include managers as a separate occupational group, perhaps greater increases in the effect of occupation would have been found after 1991.

Altogether, while the effect of occupation did not change much after 1991, relatively strong occupation effects were generally found for lone mothers both before and after the transition. However, this was not the case for childless women. At the same level of earnings, economic difficulties may be less severe for childless women and influence their partnership formation less strongly.

Table 3 also shows evidence of an effect of employment status in the period after 1991, confirming the third hypothesis. After 1991, non-employed lone mothers had higher risks of partnership formation than those employed in most occupations. Before 1991, non-employment was very rare, and as expected, no significant effects are found.

Next to effects of employment characteristics, important effects were found for demographic variables as well. The number of children has a negative effect, and there is also a clear increase in risks of partnership formation with the age of the youngest child. It is likely that the number and age of children affect lone mothers' rates of partnership formation via time availability (de Graaf/Kalmijn 2003).

Mothers' own age is found to have a relatively strong negative effect on risks of partnership formation. Possibly, this has to do with a more difficult marriage market at older ages where fewer people of one's own age are still single (Bumpass et al 1990). The duration since the last partnership also has a negative effect on risks of partnership formation. This could reflect growing selectivity of those remaining single as time since the last partnership passes (Ermisch/Wright 1991). People who have been single for a longer time may also have become more accustomed to this lifestyle.

The results presented in Table 3 also indicate that risks of partnership formation are lower for Muslim than for Orthodox lone mothers or lone mothers with a different (or no) religious denomination. Possibly, more traditional family norms make it more difficult for Muslim lone mothers to find a new partner within their religious communities. In the North American and Western European context, Catholic women have been found to have lower rates of repartnering (Koo et al 1984; Teachman/Heckert 1985; Chiswick/ Lehrer 1990; Sweeney 1997; Wu/Schimmele 2005). An explanation may be that, since the Catholic church is opposed to divorce and remarriage, it is difficult for Catholic lone mothers to remarry within their cultural community (Chiswick/Lehrer 1990). Sweeney 
(1997) also argues that since the Catholic church traditionally forbids divorce, those Catholics who do get divorced may be a select group with particularly negative experiences of marriage and little interest in remarrying.

Table 3 shows that risks of partnership formation are higher in villages than in larger towns and cities. I would suspect that this may be due to greater difficulties of finding employment and being economically self-sufficient for women in rural regions. It may also be less common for women to be land-owners and run agricultural businesses. Thus, there may be stronger economic incentives for partnership formation in rural areas. I would assume that another reason is that women in rural areas have a better position in the marriage market, since more women than men tend to migrate away from rural areas. Very similar effects of settlement size have been found for the North American context (Mott/Moore 1983; Duncan/Hoffmann 1985; Dooley/Finnie 2008). One explanation provided by Mott and Moore (1983) is that rural areas provide fewer life-style alternatives to marriage.

Table 3: Relative partnership entry rates

\begin{tabular}{|c|c|c|}
\hline & $\begin{array}{c}\text { model 1: } \\
\text { lone mothers }\end{array}$ & $\begin{array}{l}\text { model 2: } \\
\text { childless women }\end{array}$ \\
\hline Constant & 0.0037 & 0.0114 \\
\hline \multicolumn{3}{|l|}{ number of children } \\
\hline 1 child & 1 & \\
\hline 2 children & 0.87 & \\
\hline $3+$ children & $0.32^{* * *}$ & \\
\hline \multicolumn{3}{|c|}{ age of the youngest child } \\
\hline $0-1$ years & 1 & \\
\hline $2-4$ years & 1.12 & \\
\hline $5-9$ years & $1.36^{*}$ & \\
\hline $10-14$ years & $1.57^{* *}$ & \\
\hline \multicolumn{3}{|c|}{ duration since last partnership } \\
\hline no previous partner & 1 & 1 \\
\hline $0-1$ years & $1.94^{* \star *}$ & $1.24^{*}$ \\
\hline $2-3$ years & $1.38^{* *}$ & 1.21 \\
\hline $4-5$ years & $1.88^{* * *}$ & 0.93 \\
\hline $6-7$ years & $1.55^{\star *}$ & 0.93 \\
\hline $8+$ years & 1.35 & $0.55^{\star \star *}$ \\
\hline \multicolumn{3}{|l|}{ pregnancy } \\
\hline pregnant & $3.52^{\star * *}$ & $8.84^{* * *}$ \\
\hline not pregnant & 1 & 1 \\
\hline \multicolumn{3}{|l|}{ Age } \\
\hline $17-19$ & $3.00^{\star * *}$ & 1.02 \\
\hline $20-24$ & $1.47^{* * *}$ & $1.51^{* * *}$ \\
\hline $25-29$ & 1 & 1 \\
\hline $30-34$ & $0.72^{\star \star \star}$ & $0.67^{\star \star \star}$ \\
\hline $35-39$ & $0.39^{* * *}$ & $0.49^{* * *}$ \\
\hline $40+$ & $0.24^{* * *}$ & $0.24^{* * *}$ \\
\hline
\end{tabular}




\begin{tabular}{|c|c|c|}
\hline & $\begin{array}{c}\text { model 1: } \\
\text { lone mothers }\end{array}$ & $\begin{array}{l}\text { model 2: } \\
\text { childless women }\end{array}$ \\
\hline \multicolumn{3}{|l|}{ place of residence } \\
\hline regional, territorial, or republican center & 1 & 1 \\
\hline other town/city & 0.96 & $1.11^{* *}$ \\
\hline urban-type village & 1.33 & 1.13 \\
\hline Village & $1.30^{\star *}$ & $1.17^{* * *}$ \\
\hline \multicolumn{3}{|l|}{ Moscow/St. Petersburg } \\
\hline no & 1 & 1 \\
\hline yes & 0.85 & 1.04 \\
\hline \multicolumn{3}{|l|}{ religious denomination } \\
\hline orthodox & 1 & 1 \\
\hline Islam & $0.58^{*}$ & $0.75^{\star * *}$ \\
\hline other & 1.02 & 1.05 \\
\hline \multicolumn{3}{|l|}{ interaction occupation/time period } \\
\hline \multicolumn{3}{|l|}{$1966-91$} \\
\hline unqualified workers & 1.16 & 0.93 \\
\hline qualified manual workers & 1.26 & 1.01 \\
\hline worker in the service sector & $1.73^{* *}$ & 1.20 \\
\hline office/clerical employees & $1.59^{*}$ & 0.97 \\
\hline professionals w. post-sec. education & 1.21 & 1.13 \\
\hline prof. w. post-sec in med., teach, nat. & 1.29 & 1.17 \\
\hline prof. w. university ed./senior, top managers & 1.08 & 1.05 \\
\hline non-employed & 1.44 & 1.12 \\
\hline education & 1.38 & $0.60^{* * *}$ \\
\hline maternity leave & $1.71^{\star *}$ & 1.03 \\
\hline \multicolumn{3}{|l|}{ 1992-2004 } \\
\hline unqualified workers & 1 & 1 \\
\hline qualified manual workers & $1.47^{*}$ & 1.09 \\
\hline workers in the service sector & $1.87^{* * *}$ & 0.93 \\
\hline office/clerical employees & 1.12 & 1.05 \\
\hline professionals w. post-sec education & 1.15 & 0.94 \\
\hline prof. w. post-sec in med., teach, nat. & 1.45 & 0.80 \\
\hline prof. w. university ed./senior, top managers & 1.07 & 0.99 \\
\hline non-employed & $1.80^{* * *}$ & 1.17 \\
\hline education & 1.65 & $0.65^{\star * *}$ \\
\hline maternity leave & 1.01 & 0.76 \\
\hline \multicolumn{3}{|l|}{ work hours } \\
\hline \multicolumn{3}{|l|}{$1966-91$} \\
\hline full-time employed & 1 & 1 \\
\hline part-time employed & 1.44 & 0.88 \\
\hline \multicolumn{3}{|l|}{ 1992-2004 } \\
\hline full-time employed & 1 & 1 \\
\hline part-time employed & 1.27 & 0.99 \\
\hline $\mathrm{N}$ & 1527 & 4310 \\
\hline
\end{tabular}

$* * *: \mathrm{p}<0.01 ; * *: 0.01 \leq \mathrm{p}<0.05 ; *: 0.05 \leq \mathrm{p}<0.1$ 


\section{Conclusion}

In the post-transition period in Russia, lone mother families were the ones to suffer most from rising poverty rates. Economic inequalities generally rose after 1991, and inequalities between women working in different occupations increased as well. Thus, the question in this study is whether rising economic inequalities and increased economic hardships for some groups of lone mothers influenced other areas of their life courses as well.

Faced with economic difficulties, lone mothers may decide to begin a new partnership more quickly than under other circumstances. This study does find evidence of higher partnership formation rates among lone mothers with lower economic resources in Russia, both before and after 1991. For instance, lone mothers who were working in service occupations had substantially higher rates of partnership formation than lone mothers working in professional occupations requiring a university degree.

However, a further hypothesis had been that occupational differences in partnership formation rates would grow larger for lone mothers after 1991, along with growing earnings inequalities. Yet, the empirical analyses showed only slight increases in the effect of occupation on partnership formation rates for lone mothers after 1991. This could indicate that there is an upper limit to the influence of lone mothers' economic situation on partnership entry rates. Lone mothers may not be able to adjust their partnership formation rates indefinitely.

Altogether, the transition in 1991 in Russia had significant implications for lone mothers' economic situation and led to elevated poverty rates particularly in the mid1990s. Earnings inequalities by qualification and occupation grew. However, the changes brought about by the transition did not lead to much greater divergences in rates of partnership formation by occupation than before the transition. Thus, it appears that growing economic inequalities had only a limited impact on this further area of lone mothers' life course. In general, however, lone mothers' socio-economic status did appear to influence their rates of partnership formation in Russia, both before and after the transition.

\section{References}

Blau, P. M. (1994). Structural contexts of opportunities. Chicago: The University of Chicago Press.

Blossfeld, H.-P. \& Timm, A. (1997). Der Einfluss des Bildungssystems auf den Heiratsmarkt. Eine Längsschnittanalyse der Wahl des ersten Ehepartners im Lebenslauf. Kölner Zeitschrift für Soziologie und Sozialpsychologie, 49, 3, pp. 440-476.

Blossfeld, H.-P. \& Timm, A. (Eds.) (2003). Who marries whom? Educational systems as marriage markets in modern societies. Dordrecht: Kluwer Academic Publishers.

Böheim, R. \& Ermisch, J. F. (1998). Analysis of the dynamics of lone parent families. Report to the Department of Social Security. University of Essex, Institute for Social and Economic Research (Working Papers of the Institute for Social and Economic Research, 1998-08).

Brainerd, E. (2000). Women in transition: Changes in gender wage differentials in Eastern Europe and the former Soviet Union. Industrial and Labor Relations Review 54, 1, pp. 138-162.

Bumpass, L., Sweet, J. \& Martin, T. C. (1990). Changing patterns of remarriage. Journal of Marriage and the Family, 52, 3, pp. 747-756.

Chiswick, C. U. \& Lehrer, E. L. (1990). On marriage-specific human capital. Its role as a determinant of remarriage. Journal of Population Economics, 3, pp. 193-213. 
de Graaf, P. M. \& Kalmijn, M. (2003). Alternative routes in the remarriage market: Competing-risk analyses of union formation after divorce. Social Forces, 81, 4, pp. 1459-1498.

Dooley, M. \& Finnie, R. (2008). Welfare policy, language group, and the duration of lone motherhood spells. Canadian Public Policy/Analyse de Politiques, 34, 1, pp. 37- 64.

Duncan, G. J. \& Hoffmann, S. D. (1985). A reconsideration of the economic consequences of marital dissolution. Demography, 22, 4, pp. 485-497.

Ermisch, J. F. \& Wright, R. E. (1991). The duration of lone parenthood in Great Britain. European Journal of Population, 7, pp. 129-158.

Federal State Statistics Service (Ed.) (2005). Russia in Figures. Moscow: Federal State Statistics Service.

Generations and Gender contextual data base. http://www.demogr.mpg.de/.

Gerber, T. P. \& Hout, M. (1998). More shock than therapy: Market transition, employment, and income in Russia, 1991-1995. American Journal of Sociology 104, 1, pp. 1-50.

Gustafsson, B., Li Shi, Nivorozhkina, L. \& Katz, K. (2001). Rubles and yuan: Wage functions for urban Russia and China at the end of the 1980s. Economic Development and Cultural Change, 50, 1, pp. $1-17$.

Hansberry, R. (2004). An analysis of gender wage differentials in Russia from 1996-2002. Ann Arbor: University of Michigan. William Davidson Institute (William Davidson Institute Working Paper 720).

Hoem, J. M., Kostova, D., Jasilioniene, A. \& Mureşan, C. (2009). Traces of the Second Demographic Transition in four selected countries in Central and Eastern Europe: Union formation as a demographic manifestation. European Journal of Population, 25, 3, pp. 239-255.

Jenkins, S., Ermisch, J. \& Wright, R. (1990). 'Adverse selection' features of poverty amongst lone mothers. Fiscal Studies, 11, 2, pp. 76-90.

Kanji, S. (2004). The route matters: Poverty and inequality among lone-mother households in Russia. Feminist Economics 10, 2, pp. 207-225.

Koo, H. P., Suchindran, C. M. \& Griffith, J. D. (1984). The effects of children on divorce and remarriage: A multivariate analysis of life table probabilities. Population Studies, 38,3, pp. 451-471.

Lampard, R. \& Peggs, K. (1999). Repartnering: The relevance of parenthood and gender to cohabitation and remarriage among the formerly married. British Journal of Sociology, 50, 3, pp. 443-465.

Le Bourdais, C., Desrosiers, H. \& Laplante, B. (1995). Factors related to union formation among single mothers in Canada. Journal of Marriage and the Family, 57, 2, pp. 410420.

Lefebvre, P. \& Merrigan, P. (1998). The impact of welfare benefits on the conjugal status of single mothers in Canada: Estimates from a hazard model. The Journal of Human Resources, 33, 3, pp. 742-757.

Lokshin, M. (2004). Household childcare choices and women's work behavior in Russia. The Journal of Human Resources, 39, 4, pp. 1094-1115.

Lokshin, M., Harris, K. M. \& Popkin, B. M. (2000). Single mothers in Russia: Household strategies for coping with poverty. World Development 28,12 , pp. 2183-2198.

McKinney, J. R. (2004). Lone mothers in Russia: Soviet and post-Soviet policy. Feminist Economics 10, 2, pp. 37-60.

Meggiolaro, S. \& Ongaro, F. (2008). Repartnering after marital dissolution: Does context play a role? Demographic Research, 19, 57, pp. 1913-1934.

Mott, F. L. \& Moore, S. F. (1983). The tempo of remarriage among young American women. Journal of Marriage and the Family, 45, 2, pp. 427-436.

Newell, A. \& Reilly, B. (1996). The gender wage gap in Russia: Some empirical evidence. Labour Economics, 3, pp. 337-356.

Newell, A. \& Reilly, B. (1999). Rates of return to educational qualifications in the transition economies. Education Economics, 7, 1, pp. 67-84.

Oberemko, O. A. (2006). Household spending on preschool education and upbringing. Russian Education and Society, 48, 12, pp. 38-63.

Ogloblin, C. G. (1999). The gender earnings differential in the Russian transition economy. Industrial and Labor Relations Review, 52, 4, pp. 602-627. 
Pascall, G. \& Manning, N. (2000). Gender and social policy: Comparing welfare states in Central and Eastern Europe and the former Soviet Union. Journal of European Social Policy, 10, 3, pp. 240-266.

Philipov, D. \& Jasilioniene, A. (2008). Union formation and fertility in Bulgaria and Russia: A life table description of recent trends. Demographic Research, 19, 62, pp. 2057-2114.

Rieck, D. (2006). Transition to second birth - The case of Russia. Rostock: Max Planck Institute for Demographic Research (MPIDR Working Paper 2006-036).

Skopek, J., Schulz, F. \& Blossfeld, H.-P. (2011). Who contacts whom? Educational homophily in online mate selection. European Sociological Review, 27, 2, pp. 180-195.

Smock, P. J. (1990). Remarriage patterns of black and white women: Reassessing the role of educational attainment. Demography, 27, 3, pp. 467-73.

Sweeney, M. M. (1997). Remarriage of women and men after divorce: The role of socioeconomic prospects. Journal of Family Issues, 18, pp. 479-502.

Teachman, J. D. \& Heckert, A. (1985). The impact of age and children on remarriage: further evidence. Journal of Family Issues, 6, pp. 185-203.

Teplova, T. (2007). Welfare state transformation, childcare, and women's work in Russia. Social Politics: International Studies in Gender, State, and Society. Special issue: Gender and state in post-communist societies, 14, 3, pp. 284-322.

Trapido, D. (2007). Gendered transition: Post-Soviet trends in gender wage inequality among young fulltime workers. European Sociological Review, 23, 2, pp. 223-237.

United Nations Economic Commission for Europe (2007). Generations \& Gender Programme. Concepts and guidelines. New York /Geneva: United Nations Economic Commission for Europe.

van der Lippe, T. \& Fodor, É. (1998). Changes in gender inequality in six Eastern European countries. Acta Sociologica, 41, pp. 131-149.

Wu, Z. \& Schimmele, C. M. (2005). Repartnering after first union disruption. Journal of Marriage and Family, 67, 1, pp. 27-36.

Submitted on/Eingereicht am: 11.07.2011

Accepted on/Angenommen am: 19.04.2012

Address of the author/Anschrift der Autorin:

Dr. Cordula Zabel

Institut für Arbeitsmarkt- und Berufsforschung/

Institute for Employment Research (IAB)

Regensburger Straße 104

90478 Nürnberg

Germany/Deutschland

E-Mail: Cordula.Zabel@iab.de 